\title{
A STUDY OF ECLOGITIC DIAMONDS AND THEIR INCLUSIONS FROM THE FINSCH KIMBERLITE PIPE, SOUTH AFRICA
}

\author{
Clare M. Appleyard, K.S. (Fanus) Viljoen and Rene Dobbe \\ GeoScience Centre, De Beers Consolidated Mines, South Africa
}

\section{INTRODUCTION}

Syngenetic mineral inclusions in diamond, whilst rare, provide vital geological information with regards to diamond formation, mantle dynamics and mantle chemistry. These diamond inclusions crystallise under the same physical conditions as diamond and, due to the chemically inert nature of diamond, are protected from further changes within the mantle. A previous study of eclogitic diamonds and their inclusions from the Finsch mine (Gurney et al., 1979) indicated that these diamonds are rare at Finsch compared to the peridotitic suite, with 12 eclogitic diamonds encountered from which 6 garnets, 4 clinopyroxenes, 1 phlogopite, 1 kyanite and 2 coesite inclusions were recovered. These eclogitic garnets and clinopyroxenes are iron-rich and contain up to $1 \mathrm{wt} \% \mathrm{MnO}$ (Gurney et al., 1979), with $\mathrm{FeO}$ contents of up to $22.6 \mathrm{wt} \%$ in the garnets. The carbon isotopic composition of these diamonds are variable, ranging from -7.86 to $-3.06 \%$, and this is marginally heavier than that of the peridotitic diamonds at Finsch (Deines et al., 1984 \& 1989). Nitrogen contents of these diamonds vary from 50 to $1639 \mathrm{ppm}$ (which is, on average, higher than that of the peridotitic diamonds from Finsch), while the aggregation state of the nitrogen show wide scatter from poorly aggregated at $7 \%$ of nitrogen in the $\mathrm{IaB}$ form to aggregated with $61 \%$ of nitrogen in the IaB form (Deines et al., 1984 \& 1989). The eclogitic diamond crystallisation event at Finsch has been dated at 1580 Ma (Richardson et al., 1990). Smith et al. (1991) found that the eclogite paragenesis from large single diamonds (1.8 to 4.2 carats) have $\mathrm{Nd}$ model ages ranging from 1443 to 2408 Ma. Ages of 1443 and $1657 \mathrm{Ma}$ in the two samples with ${ }^{87} \mathrm{Sr} /{ }^{86} \mathrm{Sr}=0.7042$ may represent the age of diamond formation (being within error of the $1580 \mathrm{Ma}$ age of Richardson). Older model ages in three other samples correspond with unsupported radiogenic $\mathrm{Sr}\left({ }^{87} \mathrm{Sr} /{ }^{86} \mathrm{Sr}=\right.$ 0.7095 to 0.7158$)$ and anomalously high $\mathrm{MnO}(0.7$ to $1.2 \mathrm{wt} \%$ in garnet) suggestive of multistage evolution. Carbon isotopic composition of the diamonds range from -3.6 to $-7.7 \%$, and do not correlate with isotopic or chemical features of the inclusions.

At the Roberts Victor diamond mine eclogitic garnets and clinopyroxenes are also unusually iron- and manganese-rich and are therefore similar in chemical composition to those at Finsch (Gurney et al., 1984). In this instance the diamonds are typically nitrogen-free and contain unusually light carbon with an isotopic composition on the order of $-15 \%$ (Deines et al., 1987).

In view of the small number of eclogitic inclusions previously studied from the Finsch Mine, the unusually iron- and manganese-rich nature of these inclusions at Finsch and Roberts Victor, and the distinctive stable and radiogenic isotopic trends for these diamonds and their inclusions it is desirable to characterise additional eclogitic diamonds from the Finsch Mine. A total of 93 inclusion-bearing diamonds of eclogitic paragenesis were collected from the $-12+11(3.45 \mathrm{~mm}),-11+9$ $(2.88 \mathrm{~mm})$ and the $-6+5(1.83 \mathrm{~mm})$ size fractions (Harris et al., 1979) of the run of mine production. Eight of the larger diamonds were polished into plates for cathodoluminescence studies and infrared examination of diamond growth while a further 31 diamonds were cracked to retrieve inclusions. This resulted in the successful recovery of 26 orange garnets, 20 clinopyroxenes, 3 garnet-clinopyroxene pairs (separated), 1 sulphide and 1 coesite with a tiny clinopyroxene inclusion.

\section{DIAMONDS}

The majority $(51 \%)$ of the Finsch eclogitic diamonds examined are colourless, with the remainder of the population consisting of yellow and brown diamonds. Dodecahedra are the dominant diamond morphology and only $8 \%$ of the sample suite can be considered octahedra. No cubic diamonds are present. Orange garnets are the most common form of eclogitic inclusion, having been found in $84 \%$ of the diamonds examined.

\section{INCLUSION MINERAL CHEMISTRY}

The eclogitic garnets from Finsch analysed in the present study are enriched in $\mathrm{Fe}$ and are relatively depleted in $\mathrm{Ca}$ and $\mathrm{Mg}$ relative to the world-wide database (Figure 1). $\mathrm{FeO}$ contents for garnet range from 15-27 wt $\%, \mathrm{Al}_{2} \mathrm{O}_{3}$ contents show a restricted range in compositions (20.8-22.8 wt \%) and $\mathrm{Na}_{2} \mathrm{O}$ contents are 


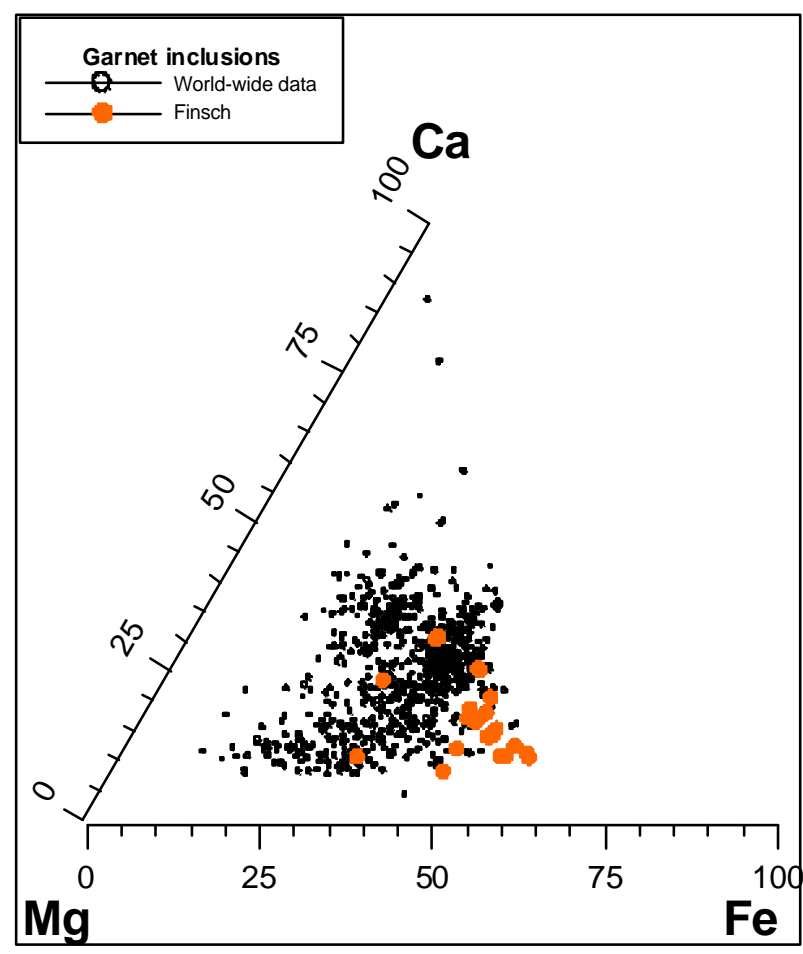

Figure 1: Ternary Ca-Mg-Fe diagram for the Finsch eclogitic diamond inclusions. Also shown for comparative purposes is data for world-wide localities (Sobolev et al., 1976; Gurney et al., 1979; Tsai et al., 1979; Gurney et al., 1984 \& 1985; Moore et al., 1986; Jaques et al., 1989; Rickard et al., 1989; Rickard et al., 1991; Smith et al., 1991; Chinn, 1995; Kopylova et al., 1997; Stachel \& Harris, 1997; Wang, 1998; McDade \& Harris, 1999; Richardson et al., 1999; Viljoen et al., 1999).

comparatively low (0.11-0.2 wt \%). Mn contents are variable and may be extremely high, with a maximum value of $1.6 \mathrm{wt} \%$ (Figure 2). The eclogitic clinopyroxenes occurring as inclusions in diamond at Finsch have relatively high $\mathrm{FeO}$ contents, up to 14.8 wt $\%$. $\mathrm{Na}_{2} \mathrm{O}, \mathrm{MgO}$ and $\mathrm{Al}_{2} \mathrm{O}_{3}$ contents are intermediate compared to world-wide localities. $\mathrm{K}_{2} \mathrm{O}$ contents are comparatively low relative to the world-wide database, reaching a maximum of $0.4 \mathrm{wt} \%$. The clinopyroxene included in the coesite shows similar mineral chemistry to the other inclusions, but has slightly lower $\mathrm{Na}_{2} \mathrm{O}$ contents and slightly higher $\mathrm{CaO}$ contents.

The three non-touching garnet clinopyroxene mineral pairs produce calculated equilibration temperatures of $1138^{\circ} \mathrm{C}, 1159^{\circ} \mathrm{C}$ and $1179^{\circ} \mathrm{C}$ at an assumed pressure of $50 \mathrm{kbar}$ and utilising the thermometer formulation of Ellis and Green (1979). These temperatures compare favourably with temperatures obtained for diamonds from Orapa but are lower than that of Argyle and
Premier (Figure 3). These temperatures also fall within the range of temperatures obtained from nitrogen aggregation states (Table 1; Evans and Qi 1982).

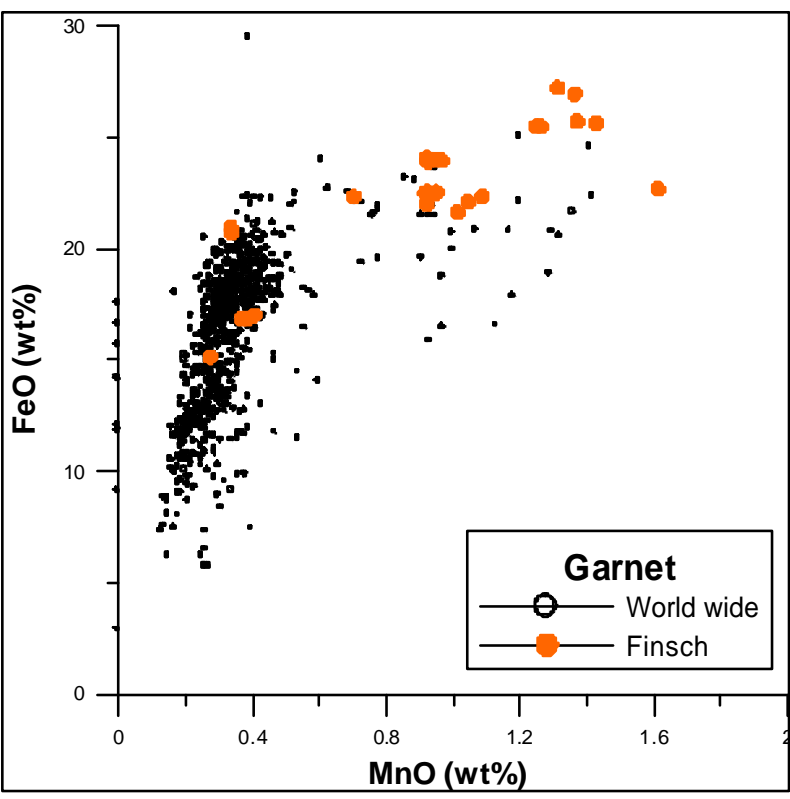

Figure $2 \mathrm{FeO}$ vs $\mathrm{MnO}$ scatter plot for Finsch eclogitic diamonds, compared to eclogitic diamond inclusions from world-wide localities (references as in Figure 1).

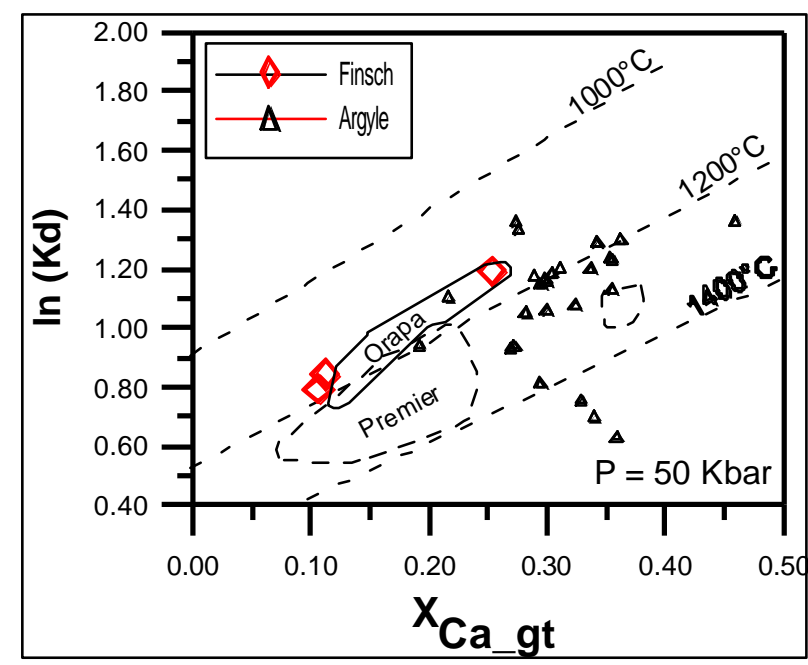

Figure 3: $\mathrm{Ln} \mathrm{Kd}$ vs $\mathrm{X}_{\mathrm{Ca} \_\mathrm{gt}}$ for the Finsch eclogites compared to other on-craton localities (Gurney et al., 1984; Jaques et al., 1986; Gurney et al., 1985). 


\section{Table 1: Equilibration temperatures for the Finsch eclogitic diamonds}

$\begin{array}{lllll}\text { Sample } & \mathbf{E G 7 9} & \mathbf{1 G a} & \mathbf{2 G a} & \mathbf{3 G a} \\ \text { F59 } & 1138^{\circ} \mathrm{C} & 1139^{\circ} \mathrm{C} & 1122^{\circ} \mathrm{C} & 1113^{\circ} \mathrm{C} \\ \mathrm{F} 90 & 1159^{\circ} \mathrm{C} & 1179^{\circ} \mathrm{C} & 1161^{\circ} \mathrm{C} & 1151^{\circ} \mathrm{C} \\ \mathrm{F92} & 1179^{\circ} \mathrm{C} & 1120^{\circ} \mathrm{C} & 1104^{\circ} \mathrm{C} & 1094^{\circ} \mathrm{C}\end{array}$

EG79 = Ellis \& Green (1979) thermometer; 1Ga, 2Ga and $3 \mathrm{Ga}$ refer to temperatures calculated using Evans \& Qi (1982) at ages of 1,2 and 3Ga respectively.

\section{DIAMOND INFRARED STUDY}

No nitrogen-free, Type II diamonds were found during this study. Five diamonds contain low nitrogen contents, less than 50ppm, which is approximately the lower limit of detection. The remainder of the diamonds are Type IaAB diamonds with total nitrogen contents ranging from $11-1520 \mathrm{ppm}$, with an average value of 585ppm. Nitrogen aggregation states are also variable, ranging from almost pure Type IaA diamond to highly aggregated Type IaAB diamond. The percentage of B-defects in the diamonds are highly variable, ranging up to $84 \%$ aggregation. Two distinct populations of diamonds on a plot of total nitrogen vs degree of aggregation suggest that the Finsch kimberlite sampled either more than one mantle source region of similar age but differing temperature, or two different populations of diamonds with different ages.

Infrared traverses across diamond plates show large intra-grain variations with regards to total nitrogen contents and aggregation states. Most of the polished plates show regular, octahedral growth zones, indicating continuous diamond growth. Decreasing nitrogen aggregation states between core and rim with decreasing nitrogen content is compatible with a slow growth process under closed system conditions.

Core-rim traverses illustrate that black zones of Type II material have the lowest nitrogen contents, and nitrogen aggregation states are commonly highest in the centre of the diamond. More complex growth patterns are illustrated by some of the diamonds (Figure 4) where a hummocky zone of cubic growth is noted in the centre of the diamond, with late stage octahedral growth visible on the corners of the diamond. Infrared traverses indicate that the highest nitrogen content and maximum nitrogen aggregation state are encountered in the cubic core of the diamond. This central cubic core is 'irregular' in that it exhibits platelet degradation (Woods, 1986).
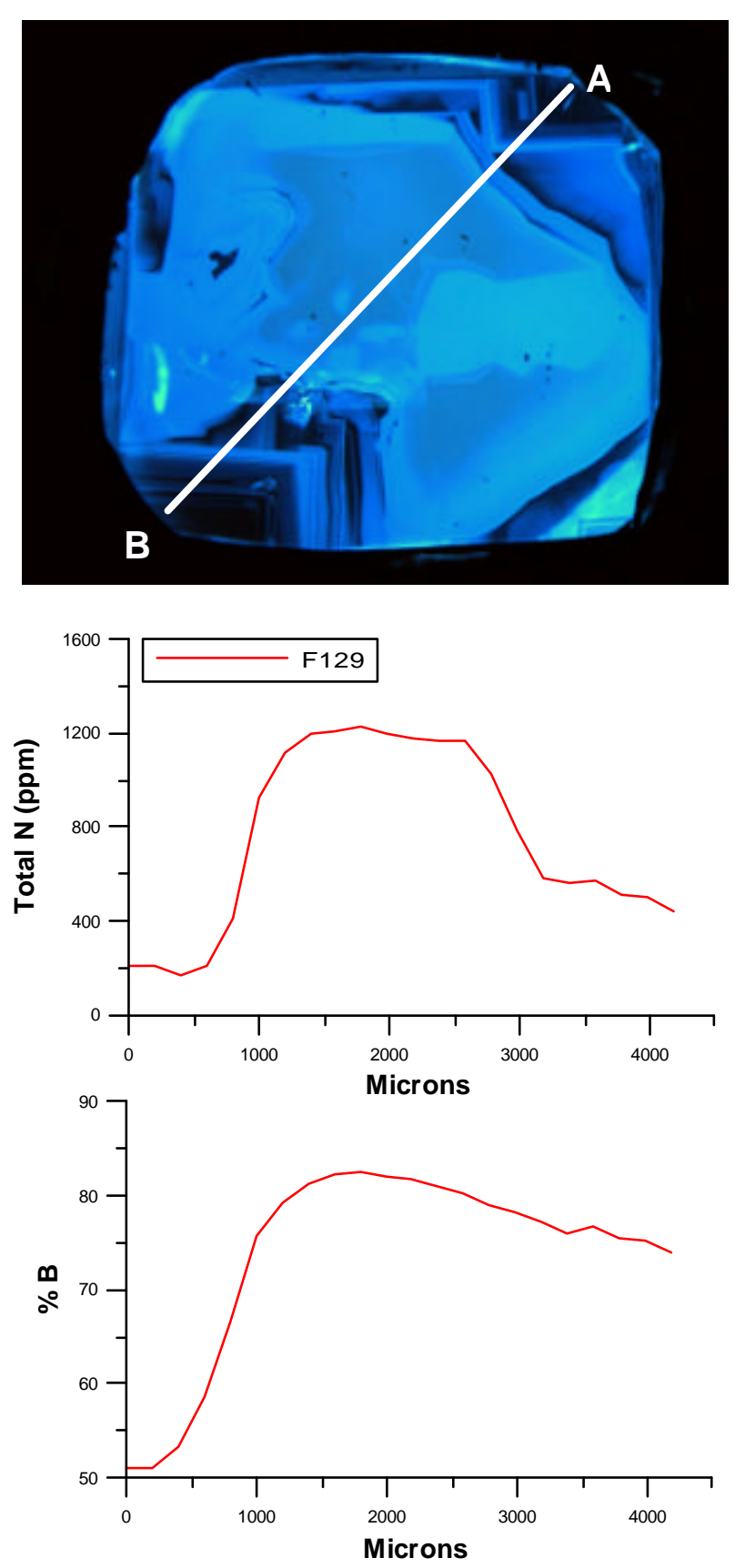

Figure 4: Finsch diamond plate F129 exhibiting both hummocky (cubic) growth and regular octahedral growth. Late stage octahedral growth on the diamond resulted in octahedral growth layers and two periods of growth are represented here. The traverses show distinctly higher nitrogen contents in the hummocky core of the diamond and lower nitrogen contents in the octahedral growth zones at the corners. 


\section{REFERENCES}

Chinn, I.L., 1995. A study of unusual diamonds from the George Creek K1 kimberlite dyke, Colorado. Ph.D. Thesis, University of Cape Town, South Africa.

Deines P., Gurney J.J., Harris J.W., 1984. Associated chemical and carbon isotopic composition variations in diamonds from Finsch and Premier kimberlite, South Africa. Geochim Cosmochim Acta 43, 325-342.

Deines P., Harris J.W., Gurney J.J., 1987. Carbon isotopic composition, nitrogen content and inclusion composition of diamonds from the Roberts Victor kimberlite, South Africa: Evidence for 13C depletion in the mantle. Geochim Cosmochim Acta 51, 12271243.

Deines P., Harris J.W., Spear P.M., Gurney J.J., 1989. Nitrogen and ${ }^{13} \mathrm{C}$ content of Finsch and Premier diamonds and their implications. Geochim Cosmochim Acta 53, 1367-1378.

Ellis, D.J., Green, D.H., 1979. Experimental study of the effect of $\mathrm{Ca}$ upon garnet-clinopyroxene $\mathrm{Fe}-\mathrm{Mg}$ exchange equilibria. Contributions to Mineralogy and Petrology 71, 13-22.

Evans, T., Qi, Z., 1982. The kinetics of aggregation of nitrogen in diamond. Proceedings of the Royal Society of London 381, 159-178.

Gurney, J.J., Harris, J.W., Rickard, R.S., 1979. Silicate and oxide inclusions in diamonds from the Finsch kimberlite pipe. In Boyd, F.R., Meyer, H.O.A. (Eds), Kimberlites, diatremes and diamonds: their geology, petrology and geochemistry. American Geophysical Union, pp. 1-15.

Gurney, J.J., Harris, J.W., Rickard, R.S., 1984. Silicate and oxide inclusions in diamonds from the Orapa Mine, Botswana. In Kornprobst, J. (Eds), Kimberlites II: The mantle and crust-mantle relationships. Elsevier, Amsterdam, pp 3-9.

Gurney, J.J., Harris, J.W., Rickard, R.S., 1984. Minerals associated with diamonds from the Roberts Victor mine. In Kornprobst, J. Eds), Kimberlites II: The mantle and crust-mantle relationships. Elsevier, Amsterdam, pp 25-32.

Gurney, J.J., Harris, J.W., Rickard, R.S., Moore, R.O., 1985. Inclusions in Premier Mine diamonds. Transactions of the geological society of South Africa 88, 301-310.
Harris J.W., Hawthorne J.B., Oosterveld M.M., 1979. Regional and local variations in the characteristics of diamonds from Southern African kimberlites. In Boyd, F.R., Meyer, H.O.A. (Eds), Kimberlites, diatremes and diamonds: their geology, petrology and geochemistry. American Geophysical Union, pp. $27-$ 41.

Jaques, A.L., Hall, A.E., Sheraton, J.W., Smith, C.B., Sun, S.S., Drew, R.M., Foudoulis, C., Ellingsen, K., 1989. Composition of crystalline inclusions and $\mathrm{C}$-isotopic composition of Argyle and Ellendale diamonds. In Ross, J., Jaques, A.L., Ferguson, J., Green, D.H., O’Reilly, S.Y., Danchin, R.V., Janse, A.J.A. (Eds), Kimberlites and related rocks Volume 2: Their mantle/crust setting, diamonds and diamond exploration. GSA Special Publication 14, 966-989.

Kirkley, M.B., Gurney, J.J., Rickard, R.S., 1991. Jwaneng framesites: carbon isotopes and intergrowth compositions. In Meyer, H.O.A., Leonardos, O.H. (Eds), Proceedings of the $5^{\text {th }}$ International Kimberlite Conference Volume 2: Diamonds: Characterisation, genesis and exploration, 127-135

Kopylova, M.G., Gurney, J.J., Daniels, L.R.M., 1997. Mineral inclusions in diamonds from the River Ranch kimberlite, Zimbabwe. Contributions to Mineralogy and Petrology 129, 366-384.

McDade, P., Harris, J.W., 1999. Syngenetic inclusion bearing diamonds from Letseng-la-Terai, Lesotho. In Gurney, J.J., Gurney, J.L., Pascoe, M.D., Richardson, S.H. (Eds), Proceedings of the $7^{\text {th }}$ International Kimberlite Conference Volume 2, 557-565.

Moore, R.O., 1986. A study of the kimberlites, diamonds and associated rocks and minerals from the Monastery Mine, South Africa. Ph.D. Thesis, University of Cape Town, South Africa.

Richardson S.H., Erlank A.J., Harris J.W., Hart S.R., 1990. Eclogitic diamonds of Proterozoic age from Cretaceous kimberlites. Nature 346, 54-56.

Richardson, S.H., Chinn, I.L., Harris, J.W., 1999. Age and origin of eclogitic diamonds from the Jwaneng kimberlite, Botswana. In Gurney, J.J., Gurney, J.L., Pascoe, M.D., Richardson, S.H. (Eds), Proceedings of the $7^{\text {th }}$ International Kimberlite Conference Volume 2, 709-713.

Rickard, R.S., Harris, J.W., Gurney, J.J., Cardoso, P., 1989. Mineral inclusions in diamonds from Koffiefontein Mine. In Ross, J., Jaques, A.L., Ferguson, J., Green, D.H., O'Reilly, S.Y., Danchin, R.V., Janse, A.J.A. (Eds), Kimberlites and related rocks Volume 2: Their mantle/crust setting, diamonds and diamond exploration. GSA Special Publication 14, 1054-1062. 
Smith, C.B., Gurney, J.J., Harris, J.W., Otter, M.L., Kirkley, M.B., Jagoutz, E., 1991. Neodymium and strontium isotope systematics of eclogite and websterite paragenesis inclusions from single diamonds, Finsch and Kimberley Pool, RSA. Geochimica et Cosmochimica Acta 55, 2579-2590.

Stachel, T., Harris, J.W., 1997. Syngenetic inclusions in diamond from the Birim fields (Ghana) - a deep peridotitic profile with a history of depletion and reenrichment. Contributions to Mineralogy and Petrology 127, 336-352.

Sobolev, N.V., Lavrentyev, Y.G., Pokhilenko, N.P., Ponomarenko, A.I.G., Sobolev, V.S., 1976. Diamondbearing grospydite and diamond-bearing disthene eclogites from the kimberlite pipe "Udachnaya", Yakutia. Dokl. Akad. Nauk SSSR 226, 927-930

Tsai, H., Meyer, H.O.A., Moreau, J., Milledge, H.J., 1979. Mineral inclusions in diamond: Premier, Jagersfontein and Finsch kimberlites, South Africa, and Williamson Mine, Tanzania. In Boyd, F.R., Meyer, H.O.A. (Eds), Kimberlites, diatremes and diamonds: their geology, petrology and geochemistry. American Geophysical Union, pp. 16-26.

Viljoen, K.S., Phillips, D., Harris, J.W., Robinson, D.R., 1999. Mineral inclusions in diamonds from the Venetia kimberlites, Northern Province, South Africa. In Gurney, J.J., Gurney, J.L., Pascoe, M.D. Richardson, S.H. (Eds), Proceedings of the $7^{\text {th }}$ International Kimberlite Conference Volume 2, 888895.

Wang, W., 1998. Formation of diamond with mineral inclusions of "mixed" eclogite and peridotite paragenesis. Earth and Planetary Science Letters 160, 831-843.

Woods, G.S., 1986. Platelets and the infrared absorption of Type Ia diamonds. Proceedings of the Royal Society of London 407, 219-238.

Contact: CM Appleyard, PO Box 82232, Southdale, 2135,

South Africa, E-mail: clare.appleyard@ debeersgroup.com 